\title{
Phthalate Release trom Plastic Fragments and Degradation in Seawater
}

\author{
Andrea Paluselli, ${ }^{\dagger}$ Vincent Fauvelle, $^{\dagger}$ François Galgani, ${ }^{\ddagger}$ and Richard Sempéré ${ }^{* \dagger}$ \\ †Aix-Marseille University; Université de Toulon, CNRS, IRD, Mediterranean Institute of Oceanography (M I O), 13288 Marseille, \\ France \\ ${ }^{\ddagger}$ IFREMER, Laboratoire Environnement Ressources, Provence Azur Corse (LER/PAC), Ifremer Centre de Méditerranée, ZP de \\ Bregaillon, 83500 La Seyne sur Mer, France
}

Supporting Information

ABSTRACT: Plastic debris in the environment contains plasticizers, such as phthalates (PAEs), that can be released during plastic aging. Here, two common plastic materials, an insulation layer of electric cables (polyvinyl chloride, PVCcables) and plastic garbage bag (polyethylene, PE-bags), were incubated in natural seawater under laboratory conditions, and the PAE migration to the seawater phase was studied with varying light and bacterial conditions over a 90-day time course. Free PAEs diluted in seawater were also studied for bacterial degradation. Our results showed that, within the first month of incubation, both plastic materials significantly leached out PAEs into the surrounding water. We found that di-isobutyl phthalate (DiBP) and di- $n$-butyl phthalate

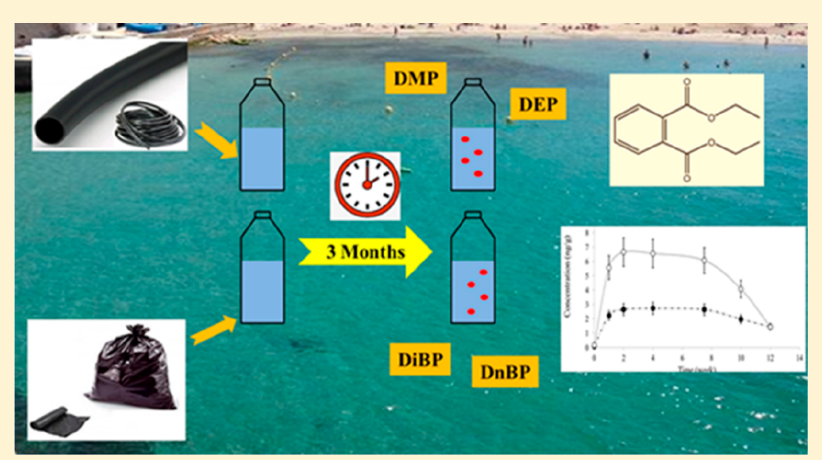
$(\mathrm{DnBP})$ were the main PAEs released from the PE-bags, with the highest values of $83.4 \pm 12.5$ and $120.1 \pm 18.0 \mathrm{ng} \mathrm{g}^{-1} \mathrm{of}$ plastic, respectively. Furthermore, dimethyl phthalate (DMP) and diethyl phthalate (DEP) were the main PAEs released from PVC-cables, with mass fractions as high as $9.5 \pm 1.4$ and $68.9 \pm 10.3 \mathrm{ng} \mathrm{g}^{-1}$, respectively. Additionally, we found that light and bacterial exposure increased the total amount of PAEs released from PVC-cables by a factor of up to 5, whereas they had no influence in the case of PE-bags.

\section{INTRODUCTION}

The worldwide production of plastics has increased considerably since the development of synthetic polymers in the middle of the 20th century, ${ }^{1,2}$ reaching 335 million tons of plastic produced globally in $2016^{2}$ and giving rise to large emissions and transport of plastic debris ${ }^{3,4}$ through rivers, sewage, and the atmosphere toward the ocean. ${ }^{5}$ Plastic materials are dispersed by winds and currents, and significant amounts may either sink into the water column, ${ }^{6,7}$ incorporate into sediments, ${ }^{8,9}$ or be assimilated by organisms. ${ }^{10}$ Although plastic degradation processes are extremely slow, ${ }^{5,11}$ more than $90 \%$ of the plastic debris, by numbers, is generally smaller than $5 \mathrm{~mm}$ (microplastic (MP) $<5 \mathrm{~mm}$ ) in aquatic systems. ${ }^{3,12}$ These particles find their origins in primary MPs, but most importantly in secondary MPs that are the result of a series of physical, chemical, and biological macroplastic degradation processes, ${ }^{1,13-15}$ which are intensified in coastal environments due to higher seawater dynamics and abrasion induced by sand/coastline. ${ }^{16}$ MPs may otherwise be assimilated and transferred into the whole marine food web, ${ }^{10,17-20}$ including marine mammals. ${ }^{21,22}$

Most plastics contain a number of additives such as phthalic acid esters or phthalates (PAEs) that are used as plastic softeners ${ }^{23,24}$ and are considered priority pollutants by the US-
EPA, the European Union (EU), and the Chinese water regulations ${ }^{25}$ due to their endocrine disruption and carcinogenic properties. ${ }^{26-30}$ Importantly, PAEs are not covalently bound to the plastic polymer and are thus likely to leach out of the plastic into the environment or inside an animal's stomach or tissue ${ }^{1}$ during abiotic/biotic aging, although little is known regarding these processes. Although PAEs have been detected in aquatic environments, ${ }^{24,31-36}$ there is a paucity of data dealing with the preferential pathway driving their introduction in aqueous marine media, the kinetics of their release from various plastic materials, and their degradation processes. ${ }^{37,38}$ The Mediterranean Sea is a semienclosed basin with high solar radiation $^{39}$ and high atmospheric inputs, ${ }^{40,41}$ a slow turnover time of $\sim 80$ years ${ }^{42}$ and strong urbanization with a large range of industrial activities spread all along the Mediterranean basin, ${ }^{43}$ which is greatly affected by marine litter. ${ }^{3,12,14,31,44-46}$ Here, we investigated in laboratory (i) the potential for commercially available plastic material to release PAEs into the surrounding seawater under varying light exposure, bacterial 
density, and temperature and (ii) the biodegradation of seven common PAEs diluted in Mediterranean coastal seawater.

\section{EXPERIMENTAL PROCEDURES}

Seawater Sampling and Pretreatment. For all laboratory experiments, a pool of $100 \mathrm{~L}$ of seawater was collected in Marseille Bay (NW Mediterranean Sea: $43^{\circ} 16^{\prime} \mathrm{N}$; $05^{\circ} 20^{\prime} \mathrm{E}$ ) in June 2015 at a $3 \mathrm{~m}$ depth by using a $12 \mathrm{~L}$ GO-FLO (General Oceanics) bottle. The bottle was previously rinsed with $1 \%$ hydrochloric acid and ultrapure water (Milli-Q resistivity > 18.2 $\mathrm{M} \Omega$ ) to prevent contamination. The water was then transferred in 5 and $10 \mathrm{~L}$ glass bottles and brought back in the laboratory within $1 \mathrm{~h}$. Then, the seawater was directly filtered in an ISO class 6 cleanroom (temperature, $22{ }^{\circ} \mathrm{C}$; SAS pressure, $+15 \mathrm{~Pa}$; SAS brewing rate, $30 \mathrm{vol} \mathrm{h}^{-1}$; lab pressure, +30 Pa; brewing rate, $\left.50 \mathrm{vol} \mathrm{h}^{-1}\right)$ through precombusted (450 ${ }^{\circ} \mathrm{C}$ for $\left.6 \mathrm{~h}\right) \mathrm{GF} / \mathrm{C}$ filters $(1.2 \mu \mathrm{m}$ retention size and $47 \mathrm{~mm}$ diameter, which was rinsed with $2 \mathrm{~L}$ of Milli-Q and $150 \mathrm{~mL}$ of sample prior to filtration) in a precombusted glass apparatus, transferred into $1 \mathrm{~L}$ glass bottles and stored for $2-3 \mathrm{~h}$ at $4{ }^{\circ} \mathrm{C}$ for further experiments. Physiochemical properties, bacterial abundance, and $\Sigma$ PAEs concentration of the sample are reported in Table S1.

PAE Release from Plastic Material Experiments. For the PAE release experiments, two commercially available plastic types were selected: one black plastic garbage bag $(2$ fragments of $2 \mathrm{~cm} \times 2 \mathrm{~cm} \times 10 \mu \mathrm{m}$, total mass of $0.4 \mathrm{~g}, 8.1 \mathrm{~cm}^{2}$ surface area) and one insulation layer from an electrical cable ( 2 tube fragments of $1 \mathrm{~cm}$ length, $9 \mathrm{~mm}$ O.D., $5 \mathrm{~mm}$ I.D., total mass of $1.5 \mathrm{~g}, 4.8 \mathrm{~cm}^{2}$ surface area). Both materials were analyzed by Fourier transform infrared spectroscopy (FTIR attenuated total reflectance, Thermo Scientific Nicolet iS50 FT-IR, $4000-600 \mathrm{~cm}^{-1}, 16$ scans per sample, $0.5 \mathrm{~cm}^{-1}$ resolution, Figure S1), which allowed for identifying the plastic bag as polyethylene (PE) and the electric cable as polyvinyl chloride (PVC). The plastic bag and electric cable will hence be named "PE-bag" and "PVC-cable" in the rest of the document, respectively. PE is largely used for garbage bags, and is predominant among all plastic debris found in the ocean, mainly at the ocean surface. ${ }^{12,15}$ Although less abundant than $\mathrm{PE},{ }^{12} \mathrm{PVC}$ is expected to sink rapidly through the water column to the seafloor due to its density $>1$, therefore affecting its exposure to light and then colonization by biofilm. Each type of fragment was transferred into separate $1 \mathrm{~L}$ glass bottles that were previously filled with $600 \mathrm{~mL}$ of filtered seawater $(1.2 \mu \mathrm{m}$ GF/C filters, see "Seawater Sampling and Pretreatment" section) and each bottle corresponds to one incubation time. The bottles were filled to $60 \%$ of the bottles' volume to ensure well-oxygenated conditions. Before the experiment, plastic surfaces were cleaned with Milli- $\mathrm{Q}$ and cut into pieces with metal scissors that were previously cleaned with hexane, DCM, and Milli- $Q$ water. The plastic fragments were incubated for three months under various conditions of light and bacteria content. Experimental details are given in Table 1.

Table 1. Experimental Design of PE-Bag and PVC-Cable Exposure

$\begin{array}{|cclc|}\text { experiment name } & \text { irradiation } & \text { biology } & \text { temperature }\left({ }^{\circ} \mathrm{C}\right) \\ \text { LA22 } & \text { light } & \text { abiotic } & 22 \\ \text { DA22 } & \text { dark } & \text { abiotic } & 22 \\ \text { DB22 } & \text { dark } & \text { biotic } & 22\end{array}$

The artificial light inside the thermostatic room was left on for the light samples, whereas the dark samples were wrapped up with aluminum paper and kept in cardboard boxes. Then, all "light" samples were not subjected to radiation in the UV range. The abiotic condition was obtained by poisoning the samples with $1 \mathrm{~mL}$ of $10 \mathrm{~g} \mathrm{~L}^{-1} \mathrm{HgCl}_{2}\left(17 \mathrm{mg} \mathrm{L}^{-1}\right.$ in seawater), which has been successfully used to account for abiotic conditions in a series of degradation study of a wide variety of organic contaminants (e.g., pharmaceuticals, polycyclic hydrocarbon) in various matrices (e.g., soil, sewage effluent, estuarine waters). ${ }^{47-49}$ Temperature was controlled in a thermostatic room. The bottle samples were gently swirled for a few seconds three times a day and twice during the weekend. Duplicate samples were extracted for PAE after 0, 1 , $2,4,7.5,10$, and 12 weeks of exposure. Briefly, $400 \mathrm{~mL}$ of the total $600 \mathrm{~mL}$ were transferred to another clean glass bottle, poisoned with sulfuric acid to a $\mathrm{pH} \sim 2$ to avoid any biological activity, closed with polytetrafluoroethylene-lined (PTFE) screw caps, and stored in the dark at $4{ }^{\circ} \mathrm{C}$ until analysis. The remaining $200 \mathrm{~mL}$ were used for dissolved organic carbon (DOC) measurements $(10 \mathrm{~mL}$ in duplicate in glass vials, stored at $4{ }^{\circ} \mathrm{C}$ before analysis), and prokaryote abundance determination $(1.8 \mathrm{~mL}$ transferred into cryovials and fixed with $2 \%\left(\mathrm{w} / \mathrm{v}\right.$ final dilution) formaldehyde solution and $-80{ }^{\circ} \mathrm{C}$ frozen until analysis).

PAE Bacterial Degradation Experiment. For the PAE biodegradation study, $700 \mathrm{~mL}$ of filtered seawater $(1.2 \mu \mathrm{m}$ GF/C filters, see "Seawater Sampling and Pretreatment" section) was transferred into precombusted $1 \mathrm{~L}$ glass bottle, spiked with a mixture of 7 PAEs' solution (grade > 98\%, Supelco, Bellefonte) to reach a final concentration of $1 \mu \mathrm{g} \mathrm{L}^{-1}$ in seawater, and incubated in duplicate at $22{ }^{\circ} \mathrm{C}$ for two months in the dark in a thermostated laboratory. Only 2-thirds of the bottles were filled to ensure well-oxygenated conditions. The abiotic control samples were prepared in duplicate, poisoned with sulfuric acid to a $\mathrm{pH} \sim 2$ to avoid any biological activity and measured at the end of the experiments to be able to attribute all the PAE loss to biotic processes. Aliquots of all samples were collected by using precombusted Pasteur pipettes at $0,1,2,4,7,13,21,28,35,42,49$, and 60 days for the flow cytometry analysis, as detailed in the previous section.

Phthalate Analyses. For PAE analyses, seawater samples were performed following a method described elsewhere. ${ }^{33}$ Briefly, PAEs were extracted from seawater by solid phase extraction (SPE) with a precombusted $6 \mathrm{~mL}$-glass reaction tube and $200 \mathrm{mg}$ of Oasis HLB sorbent (Waters Corporation, $30 \mu \mathrm{m}$ ). After sample percolation, PAEs were eluted by $6 \mathrm{~mL}$ of ethyl acetate and then evaporated up to a final volume of $200 \mu \mathrm{L}$ under a gentle stream of nitrogen (purity > 99.995\%). The extractions were carried out in controlled air conditions in an ISO class 6 chemistry cleanroom. The seven phthalates that were studied included dimethyl phthalate (DMP), diethyl phthalate (DEP), dipropyl phthalate (DPP), di-isobutyl phthalate (DiBP), di- $n$-butyl phthalate (DnBP), benzylbutyl phthalate (BzBP) and di-(2-ethylhexyl) phthalate (DEHP). Before use, all the glassware was kept in an acid bath overnight (10\% hydrochloric acid), combusted at $450{ }^{\circ} \mathrm{C}$ for $6 \mathrm{~h}$ and rinsed with methanol and dichloromethane. The analysis was performed using an Agilent Technologies 6850 gas chromatograph system coupled to an Agilent Technologies 5975C mass spectrometer (GC/MS) operated with electron impact ionization $(70 \mathrm{eV})$. Chromatographic separation was achieved using an Agilent HP-5MS capillary column $(30 \mathrm{~m} \times 0.25 \mathrm{~mm}$, 


\section{Light Effect}
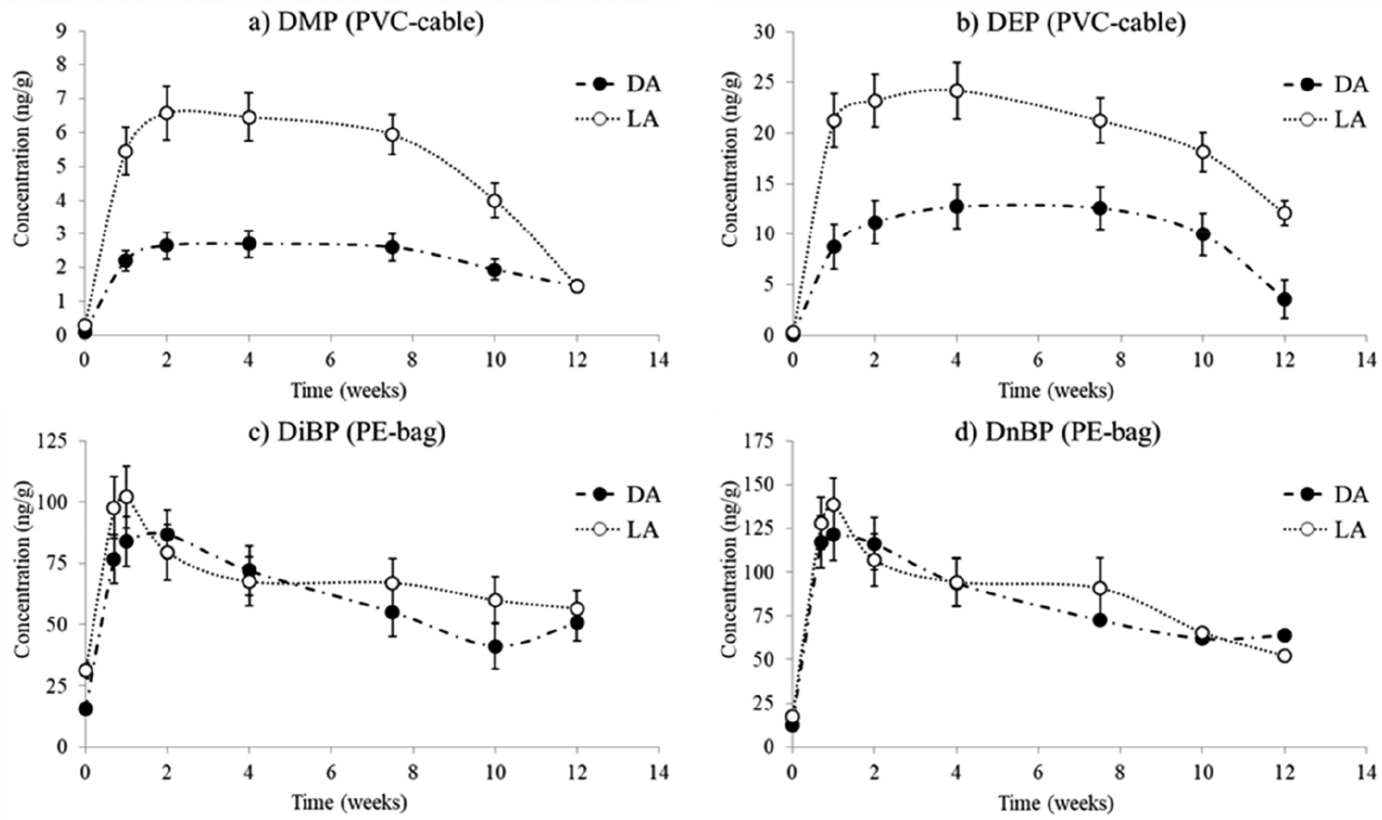

Figure 1. Graphical representation of the release kinetics of DMP (a) and DEP (b) from the PVC-cable experiments and of DiBP (c) and DnBP (d) from the PE-bag experiments. The two experimental conditions were dark abiotic (DA) and light abiotic (LA) incubated at $22{ }^{\circ} \mathrm{C}$ (in situ temperature). Curves are given to assist in the reading and do not represent data modeling.

$0.25 \mu \mathrm{m}$ film thickness). PAEs average recovery ranged from 90\% (DEHP) to $108 \%$ (DiBP). Method detection limits ranged from 0.1 to $0.9 \mathrm{ng} \mathrm{L^{-1 }}$ for DMP and DEHP, respectively. Although caution was paid to prevent contamination, DEP, DiBP, and occasionally DnBP were detected in the procedural blanks at levels that remained below $0.4-2 \%$, $2-3 \%$, and $0-4 \%$, respectively, of the masses that were measured in different seawater samples.

Heterotrophic Prokaryotes, DOC Analyses and Scanning Electron Microscopy (SEM). For the heterotrophic prokaryote determination, seawater aliquots were analyzed by using the flow cytometry core facility PRECYM of the Mediterranean Institute of Oceanology (http://precym.mio. osupytheas.fr). Immediately after sampling, the samples were thawed at room temperature and stained using SYBR Green II (Molecular Probes). The analyses were performed on a FACSCalibur flow cytometer (BD Biosciences) equipped with an air-cooled argon laser $(488 \mathrm{~nm}, 15 \mathrm{~mW}){ }^{50}$ The DOC concentrations were measured using a Shimadzu TOC5000 carbon analyzer. ${ }^{51}$ The plastic pieces were analyzed with SEM at $t_{0}$ and $t_{\mathrm{f}}$ to obtain insights into the potential surface modification of the materials. To this end, the samples were carbon-coated before being examined on two different zones with a Zeiss Supra 40VP microscope with an accelerating voltage set at $10 \mathrm{kV}$ and a working distance of $9 \mathrm{~mm}$.

\section{RESULTS AND DISCUSSION}

Release from Plastic Fragments: Light Effect. Our results indicated that, regardless of the indoor light/dark conditions, both PVC-cable and PE-bag leached specific PAEs toward the surrounding seawater, with higher release rates for the latter. Only the DMP and DEP migrations (expressed as ng $\mathrm{g}^{-1}$ of plastic incubated) were detected from the PVC-cable, whereas only DiBP and DnBP were detected from the PE-bag
(Figure 1). The absence of other targeted PAEs may be explained by (i) their absence from the selected polymers or (ii) the low release rate to the surrounding water phase due to high affinity with the polymer. In all experiments, the larger migration was measured within the first 2 weeks of incubation with a specific magnitude and trend for each individual treatment. LA22 were compared to DA22 treatment to isolate the effect of the light (Table 1).

Note that for the PVC-cable (Figure 1a,b), a higher migration was observed during the first $1-2$ weeks (up to $6.6 \mathrm{ng} \mathrm{g}^{-1}$ and $23.2 \mathrm{ng} \mathrm{g}^{-1}$ for DMP and DEP, respectively), whereas the measured concentrations reached a plateau and remained stable in both the light- and dark-abiotic conditions throughout the following 6 weeks. After 8-10 weeks, the measured concentrations started to slightly decrease, most likely due to the glass bottle adsorption or hydrolysis, ${ }^{52}$ although late prokaryotic development and subsequent biodegradation cannot be precluded. Overall, our results showed that (i) DEP was predominantly released from the PVC-cable over DMP (3.5 times more) and (ii) the indoor light condition induced up to two times more DEP and DMP releases compared to the dark condition. In contrast, for the PE-bag experiments, a higher amount of PAEs, including DiBP followed by DnBP, were released (up to $139 \mathrm{ng} \mathrm{g}^{-1}$ ) mainly during the first week. Differently from the PVC-cable experiments, the PE-bag results indicated no significant release differences between light- and dark-abiotic conditions (darkabiotic) DiBP, $83.4 \pm 12.5 \mathrm{ng} \mathrm{g}^{-1}$; and DnBP, $120.1 \pm 18.0 \mathrm{ng}$ $\mathrm{g}^{-1}$. (light-abiotic) DiBP, $103.6 \pm 15.5 \mathrm{ng} \mathrm{g}^{-1}$ and DnBP, $138.8 \pm 20.8 \mathrm{ng} \mathrm{g}^{-1}$ ) during the time course experiment (Figure 1c,d), thus suggesting that only seawater leaching promotes PAE release whatever the light conditions. Similar decreases for both dark and light conditions during the last weeks of the experiment suggest that photodegradation in the 


\section{Biotic Effect}
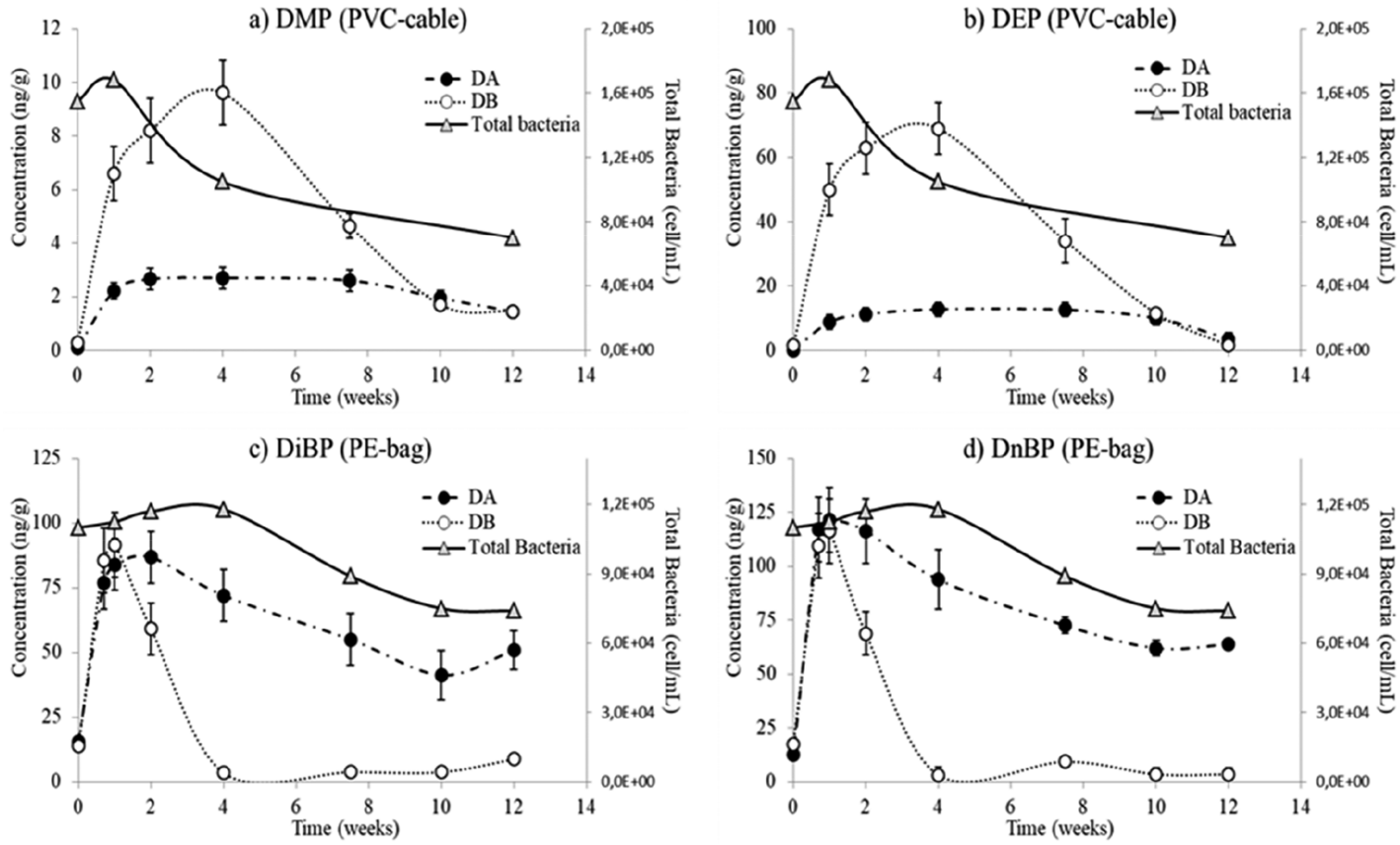

Figure 2. Graphical representation of the release kinetics of DMP (a) and DEP (b) from the PVC-cable experiments and of DiBP (c) and DnBP (d) from the PE-bag experiments. The two experimental conditions were dark abiotic (DA) and dark biotic (DB) incubated at $22{ }^{\circ} \mathrm{C}$ (in situ temperature). Total bacteria include LNA and HNA cell abundance. The curves are given to assist in the reading and do not represent the data modeling.

visible radiation range was not a significant process on freely dissolved DiBP and DnBP destruction. Therefore, the different patterns observed for both PVC-cable and PE-bag could be rather linked to the 3-dimension configuration of each plastic piece (i.e., $2 \mathrm{~mm}$ vs $10 \mu \mathrm{m}$ thicknesses, respectively). Indeed, the very thin PE-bag material could release a large part of its PAE burden either with light or not. In contrast, photochemical oxidation reactions may alter the PVC-surface, thereby making more PAE quantities water-accessible.

DOC leaching confirms the PAEs trend, with the PE-bag's highest release in the first week and small differences between the dark and light conditions $\left(24.4 \times 10^{3}\right.$ and $24.6 \times 10^{3} \mathrm{ng} \mathrm{C}$ $\mathrm{g}^{-1}$ of plastic bag) and with the PVC-cable's highest release after $1-2$ weeks and higher release during the light experiment $\left(13.4 \times 10^{3}\right.$ and $21.9 \times 10^{3} \mathrm{ng} \mathrm{C} \mathrm{g}^{-1}$ in the dark and light conditions, respectively) (Figure S2). The PAE carbon content released from the PE-bag and PVC cable thus represented a small portion of the DOC that leached, that is, only 0.05$0.09 \%$ of the DOC released from the PVC-cable and 0.15$0.17 \%$ of the DOC from the PE-bag. In addition to PAEs, other groups of organic additive or oligomers could be leached from this plastic during the experiment, thus increasing the concentration of DOC in the surrounding water. The amount of DOC leached per surface area unit of the PE-bag in this study ( 5.5 and $5.6 \mu \mathrm{g} \mathrm{C} \mathrm{cm}^{-2}$ of the plastic surface in the dark and light conditions, respectively) are higher than the migration observed by Romera-Castillo et al. (2018) in PE food packaging $\left(0.26-0.31 \mu \mathrm{g} \mathrm{C} \mathrm{cm}^{-2}\right)$, which is probably due to the lower amount of additives mixed in food plastic resins, but is in the same range of LDPE and HDPE pellets' leaching (2.4-8.9 $\mu \mathrm{g} \mathrm{C} \mathrm{cm}^{-2}$ ). In the same study, similar leaching kinetics were reported, with the peak of leaching observed in the first week of the experiment, which was followed by a sharp decrease of DOC migration during the first month. Interestingly, we observed a second strong DOC leaching after 10-12 weeks $\left(83-96 \times 10^{3} \mathrm{ng} \mathrm{C} \mathrm{g}^{-1}\right.$ for the PE bag and $28-38 \times 10^{3} \mathrm{ng} \mathrm{C} \mathrm{g}^{-1}$ for the PVC-cable), which was probably due to the initial degradation of the plastic surface. The lack of a strong weathering such as UV-exposure or a strong mechanical abrasion induced a slow degeneration of the polymers and thus, part of the organic matter pool more strongly bounded to the polymer could be leached only when the fragments were affected by major surface modifications.

Release from Plastic Fragments: Biotic Effect. Biotic effects were studied by comparing the results of the previous abiotic conditions with the PAE release kinetics from the same plastic materials diluted in seawater comprising its natural prokaryote assemblage (biotic conditions, seawater filtered through $1.2 \mu \mathrm{m} \mathrm{GF} / \mathrm{C}$ and not poisoned with $\mathrm{HgCl}_{2}$; Figure $2)$. The results indicated that $\mathrm{DiBP}$ and $\mathrm{DnBP}$ are more rapidly released and in higher proportions (up to $122 \mathrm{ng} \mathrm{g}^{-1}$ ) from the PE-bag than the DMP and DEP from the PVC-cable (63.5 ng $\left.\mathrm{g}^{-1}\right)$. Globally, the same PAEs were detected for both light and biotic experiments. However, 5-fold higher quantities of DMP/ DEP were produced from the PVC-cable in the biotic conditions during the first month rather opposed to the abiotic conditions, thus indicating that PAE leachates were promoted by prokaryotic activity. In contrast, no influence of prokaryotes was observed on the initial release of $\mathrm{DiBP}$ and DnBP from the PE-bag. PAE release catalyzed by bacterial communities seemed to be more efficient for the PVC-cable than for the PE-bag. The large difference in PAE release between biotic and abiotic conditions observed in the case of PVC-cable was not observable in the case of the PE-bag 

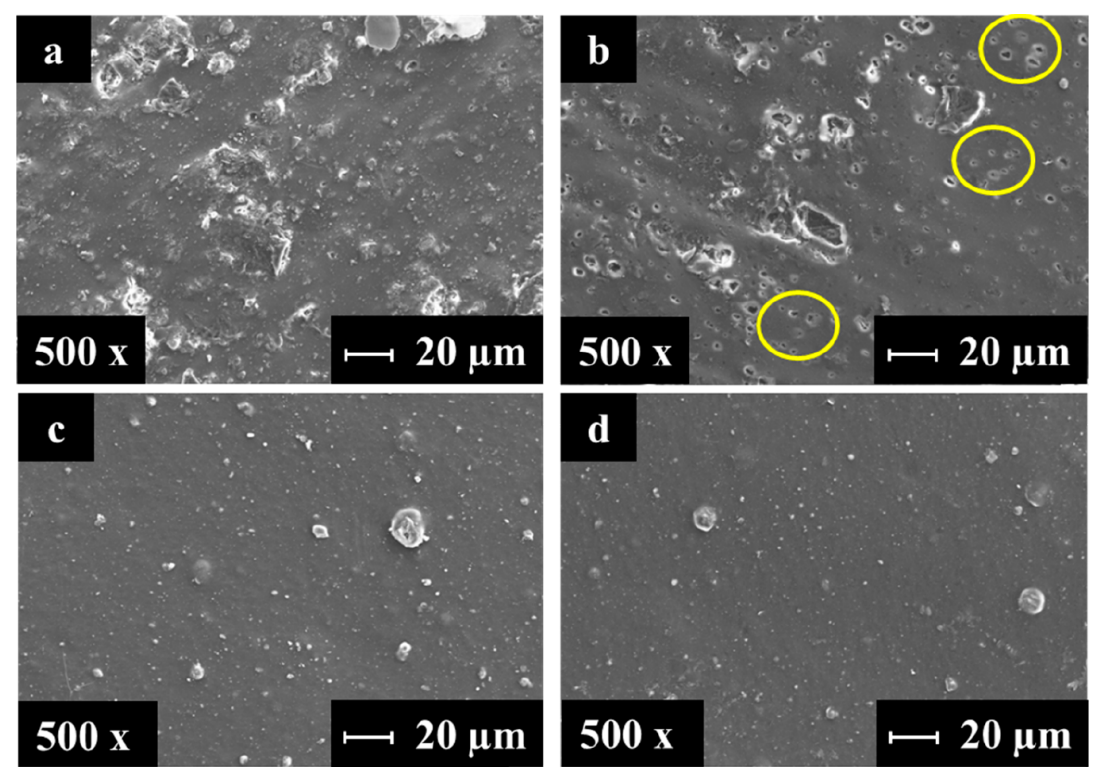

Figure 3. Surface of plastic fragments observed through SEM in the DB (dark biotic) condition at $t_{0}$ and $t_{\text {final }}$ ( 3 months). (a) PVC-cable fragments at $t_{0}$, (b) PVC-cable fragments at $t_{\text {final }}$ (c) PE-bag fragment at $t_{0}$, and (d) PE-bag fragments at $t_{\text {final }}$. The yellow circles highlight the cavities on the PVC-cable fragments after three months of incubation.

experiments. This could be attributed to (i) the low thickness of the material, thus allowing for a complete release of PAE burden regardless of the conditions or (ii) the low PE aging under the action of bacteria.

Interestingly, for both materials incubated with seawater prokaryote assemblages, an increase in the PAE concentration was followed by a net decrease of this PAE concentration, as low as almost zero after 4 and 12 weeks for the PE-bag and PVC-cable experiments, respectively, thus suggesting the subsequent assimilation of dissolved PAEs by prokaryotes. Readsorption of PAE by the plastic could also explain the decrease of PAE content in the dissolved fraction. Indeed, plastic surface modification during aging includes an increase of surface polarity, ${ }^{53}$ and therefore changes the partition coefficient of individual PAEs between water and plastic fragments. It is of importance to note that the DiBP and DnBP released from the PE-bag are more rapidly consumed by prokaryotes than the DEP and DMP produced from the PVCcable. After the beginning of the fragments incubation and PAE leaching, bacterial abundance increased probably as a result of the leached material available for prokaryote consumption and growth (Figure 2). In PE-bag experiments, the lack of available PAEs after 4 weeks corresponds to a decrease of the prokaryotic abundance. This was not observed in PVC-cable experiments, in which the growth ended after 1 week. The reason could be the smaller amount of leachate from PVC that may support a smaller community than the larger amount of leachates from PE-bag. The plastic fragments at $t_{0}$ and $t_{\text {final }}$ exposed under dark biotic conditions were observed through SEM and showed a diffuse degradation of the PVC-cable surface, with characteristic cavities along the fragments after 3 months of incubation (Figure 3a,b) and no evident differences on the PE-bag surface at the end of the incubation (Figure 3c,d). This observation seems to confirm that PVC-cable fragments are a better substrate for prokaryote colonization and subsequent degradation. This outcome may probably explain the large differences observed between the biotic and abiotic samples for the PVC-cable experiments and the lack of differences for the PE-bag experiments, whether these differences are linked to the total or only the surface PAE release, regardless of the exposure conditions. Then, this experiment indicated that DiBP and DnBP are more rapidly released from the PE-bag and quickly exhausted by prokaryotes, whereas both processes are found to be slower in the case of the PVC-cable/DMP/DEP experiment.

The observed DOC leached results are smaller or negligible compared with the two abiotic experiments in the incubation with bacteria. The DOC release of $7 \times 10^{3} \mathrm{ng} \mathrm{C} \mathrm{g}^{-1}$ was measured from the PVC-cable in the first week, and no DOC leaching was observed from the PE bag in the first weeks of the experiments. This result is probably because the plastic derived DOC is immediately available for bacterial degradation and supports the bacterial growth. The prokaryotic consumption of the plastic-derived DOC agrees with a previous study. ${ }^{15}$ Interestingly, the DOC from the PE and PVC plastics was characterized by large leaching after 10-12 weeks of incubation $\left(23 \times 10^{3}\right.$ and $36 \times 10^{3} \mathrm{ng} \mathrm{C} \mathrm{g}^{-1}$ for the PVCcable and the PE-bag, respectively), as already shown by the abiotic experiments. This kinetic is not supported by the PAE results and could be due to the release of organic substances derived from polymer degradation and weathering.

PAE Biodegradation in Seawater. A dissolved phthalate biodegradation experiment was undertaken to study the biodegradability of PAEs that could have been released from any plastic fragments in the natural environment. Our results showed that the PAE concentrations in the dark under abiotic conditions (controls) remained relatively stable over the 60 days of exposure for all compounds (Figure 4). Indeed, minor concentration changes, ranging from $-3.5 \%$ (DEP) to $-6.1 \%$ (DEHP), were observed, thus suggesting no significant abiotic degradation and slight sorption on the glass bottle ${ }^{52}$ during the time course experiment. However, under biotic conditions, 4 of the 7 target PAEs in seawater, including DnBP, DiBP, BzBP, and DEHP, were almost completely degraded (>85\%) within 

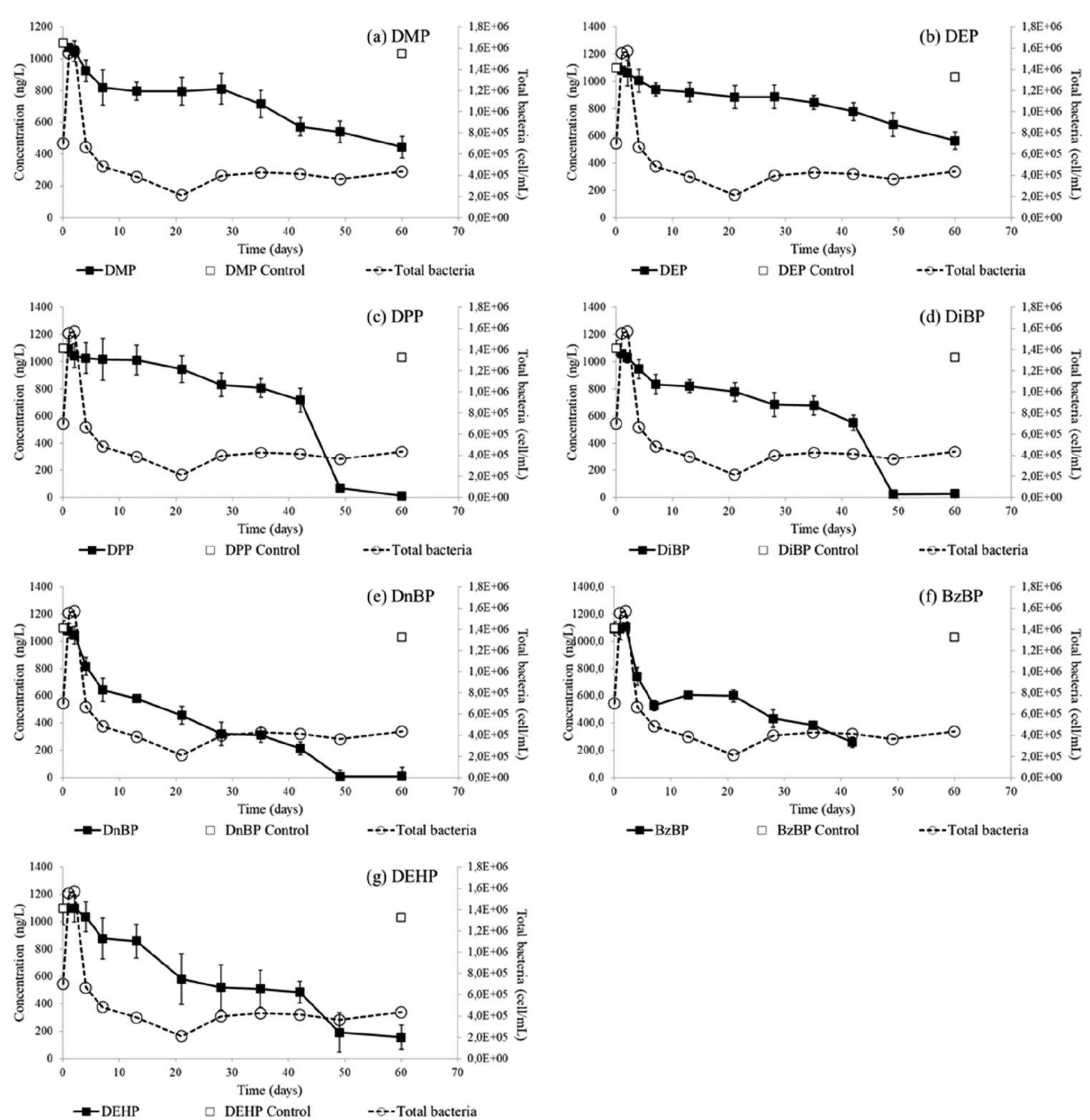

Figure 4. Bacterial degradation of the 7 PAEs in seawater at $22^{\circ} \mathrm{C}$ and in the dark condition. (a) DMP, (b) DEP, (c) DPP, (d) DiBP, (e) DnBP, (f) BzBP, and (g) DEHP kinetics of degradation. Abiotic samples poisoned with sulfuric acid were used as controls in this study at $t_{0}$ and $t_{\text {final }}$. Total bacteria include LNA and HNA cell abundance.

49 days of incubation (Figure 4), whereas $28-46 \%$ of DMP, DEP, and DPP were degraded. No significant correlations were found between bacterial abundance and PAE consumption, either as individual PAEs or as total PAEs. A first order regression (eq 1) was applied to the data to estimate the degradation rate (i.e., $k$ ) and half-life $\left(t_{1 / 2}\right.$, eq 2) (Table 2).

$$
\begin{aligned}
C_{(t)} & =C_{(t=0)} \mathrm{e}^{-k t} \\
t_{1 / 2} & =\frac{\ln 2}{k}
\end{aligned}
$$

where $C_{(\mathrm{t})}$ and $C_{(\mathrm{t}=0)}$ are the PAE concentrations at each time $t$ or $t=0$, respectively.

The calculated values of $k$ ranged from $0.046 \pm 0.005 \mathrm{~d}^{-1}$ (DnBP) to $0.009 \pm 0.001 \mathrm{~d}^{-1}$ (DEP), thus resulting in $t_{1 / 2} \mathrm{~s}$ ranging from 21 to (DnBP) to 79 days (DEP). It is of interest
Table 2. Degradation Rates $(k)$ and Half-Lives $\left(t_{1 / 2} s\right)$ of seven PAEs under Dark Biotic Conditions. A First Order Regression Was Fitted to the Experimental Data Using XLSTAT Software. The RSD (relative standard deviation) Is Applicable for both $k$ and $t_{1 / 2}$

$\begin{array}{ccccc}\text { compound } & k\left(\mathrm{~d}^{-1}\right) & t_{1 / 2}(\mathrm{~d}) & \mathrm{RSD}(\%) & R^{2} \\ \text { DMP } & 0.013 & 53 & 11.4 & 0.905 \\ \text { DEP } & 0.009 & 79 & 9.2 & 0.932 \\ \text { DPP } & 0.024 & 29 & 20.1 & 0.727 \\ \text { DiBP } & 0.024 & 29 & 20.1 & 0.822 \\ \text { DnBP } & 0.046 & 15 & 10.2 & 0.964 \\ \text { BzBP } & 0.034 & 21 & 20.8 & 0.824 \\ \text { DEHP } & 0.027 & 26 & 8.3 & 0.963\end{array}$


to note that the lowest values of $k\left(0.009-0.013 \mathrm{~d}^{-1}\right)$ were observed for the shortest chain PAEs (DMP and DEP), whereas longer and branched chain PAEs exhibited higher values $\left(0.024-0.046 \mathrm{~d}^{-1}\right)$ (Table 2), which is consistent with our PAE plastic release experiment (Figure 2). The PAEs biodegradation rate has been reported to decrease with increasing alkyl chain length as a result of the stereospecific blockade. $^{54}$ However, our results confirm this trend only between the longer chain PAEs and showed an extremely lower rate for the short chain PAEs. This behavior has been previously reported in another study, where DnBP was degraded faster than DEP, showing an inhibitory effect of DnBP on DEP, probably caused by the competition for the same enzyme active site. ${ }^{37}$ Another reason might be the production of intermediate short chain-PAE products during the long chain-PAE degradation. Indeed, monobutyl phthalate and DEP have been reported as the two major intermediate compounds of the degradation of the DiBP, DnBP, and DEHP by the primary degradation pathway and by the secondary pathway, ${ }^{54-56}$ in which PAEs with longer side chains are converted to those with shorter chains by $\beta$-oxidation, which removes one ethyl group each time until $\mathrm{DEP}^{56}$ is obtained and eventually, by further transesterification, ethyl-methyl phthalate and then DMP. ${ }^{57}$ Accordingly, DMP and DEP can be considered intermediate or end products of long chain PAE degradation oxidation reactions.

Additionally, the difference in the prokaryotic degradation is very likely the result of the specific abundance of the organisms with the specific ability to degrade individual PAEs. ${ }^{54,58}$ Note that the DEHP and DnBP biodegradation by pure cultures of bacteria isolated from activated sludge, mangrove sediments, and wastewater have been already reported, ${ }^{59-63}$ whereas several microorganisms were identified for phthalate degradation, such as Pseudomonas fluorescens, Rhodococcus rhodochrous, and Comamonas acidovoran. ${ }^{64-67}$ The already published DnBP degradation rate and half-life of the isolated bacteria ranged from 0.018 to $0.035 \mathrm{~h}^{-1}$ and from 20 to $72 \mathrm{~h}$, respectively. ${ }^{37,43,55}$ However, most of the microorganisms have been isolated from terrestrial subsurface environments, and far less is known about their counterparts in marine environments. In addition, complete phthalate degradation is always carried out syntrophically by several members of microorganisms in natural environments. ${ }^{68}$ The $k$ of DnBP and DEHP reported in several studies with mixed cultures in environmental conditions ranged from 0.015 to 0.024 $\mathrm{d}^{-1}, 54-57,69$ which is consistent with our findings (Table 2). Additionally, in an aquatic environment, PAE can also be degraded by the intra and extracellular enzymes of phytoplankton. ${ }^{37,70}$

Release from Plastic Fragments, Material Effects. The two common plastic products that were studied here, including the PE plastic trash bags and PVC electrical cables, were found to release distinct PAEs in different ways during the time course experiments. Note that an extension of these results must be taken cautiously because there is some variability in the chemical composition of these commercially available products. Indeed, trash bags, which are commonly manufactured, can be either made from plastic beads of low-density polyethylene (LDPE) and/or high-density polyethylene (HDPE), whereas the insulation sheath of electric cables can also be made of a polymer composition comprising a polymer base resin of polyethylene, ethylene-propylene rubber (EPR) or polyvinyl chloride (PVC, this study). In addition, these material layers usually contain large range additives to improve the physical proprieties and resistance to different surrounding conditions, which range from 0.5 to $5 \%$ of the weight of total polymer composition.?

PAE migration from plastic materials was already reported in cases concerning the potential release in food and water from bottles, packaging materials, and disposable tableware. ${ }^{72-81}$ The polymer has a three-dimensional porous structure in which the additives are dispersed, and the pore diameter and additive size are important parameters ${ }^{82}$ that could determine a selective release of the lower molecular weight additives, which in this case are the DMP and DEP for the PVC-cable. In addition, the depletion of these PAEs from the resin surface and a negative concentration gradient from the inside to the surface may cause the migration. ${ }^{82}$ In contrast, DEHP, which has the highest molecular weight phthalate target in this study, and the other high molecular weight PAEs are more resistant to migration due to their hydrophobicity and higher partitioning coefficient. The nature of the polymer of the insulation layer of electrical cables, which is compact and dense, and the tube-shape of the fragments used for the incubation experiments could be two factors involved in PAE selective migration in the surrounding medium. DMP and DEP could be better candidates for the migration process from this fragment of plastic if compared with DiBP, DnBP, and DEHP. However, a significant DiBP and DnBP release was observed from the plastic bags. This material was constructed by a different polymer structure that was less compact and more flexible, and the fragments used for the incubation were characterized by a larger surface to mass ratio. In addition, the two plastic materials could be made of different amounts of plasticizers since the purpose for which they have been produced and their necessary features are different. The release may take place during the service life of the plastics or their production as well as after their disposal. Moreover, due to the lower steric hindrance of DMP and DEP, it could be possible that this material has already lost most of its low molecular weight PAEs content before the incubation experiments.

Environmental Implications. Overall, these results confirm that, according to the origin and aging of the material, plastic aquatic dilution may provide variable amounts of PAEs in their surrounding environments, including seawater and the guts of marine organisms, birds and mammals. During the study period (three months), the PE-bag provided approximately 1 order of magnitude more PAEs than the PVC-cable. PAE leaching from plastics and its subsequent effects might be important in areas with high plastic concentrations ${ }^{3,11,12,83}$ and certainly contribute to the high PAE concentrations reported in coastal areas in the vicinity of large rivers and urbanized areas. ${ }^{33,34,84}$ It has been estimated that between $4.8 \times 10^{6}$ and $12.7 \times 10^{6}$ MT of plastic entered in the oceans in the year $2010,{ }^{15,85}$ with $28 \%$ and $5 \%$ being made of polyethylene and PVC, respectively. ${ }^{2}$ By extrapolating our results to the oceans, our results would suggest that between $0.32 \mathrm{MT}$ and $0.86 \mathrm{MT}$ and between 0.02 MT and 0.05 MT of PAE leach in the first two months of their introduction into the oceans every year from plastic bags and PVC-cables, respectively, and it is important to understand that the myriad of plastic items in the oceans may release different types of PAEs. Our study suggests that most of the PAEs produced are exhausted by marine prokaryotes within one month (PE-bag) and 2.5 months (PVC-cable). Similarly, intense solar radiation in the surface water ${ }^{15}$ may certainly modify the release and bioavailability of 
PAEs produced from plastics in the oceans, whereas high hydrostatic pressure in deep waters is able to modify the prokaryotic degradation of particulate organic matter ${ }^{86}$ and certainly have a significant effect on the plastic aging deposited on the deep sediment. Considering that we found that PAEs that were released ranged from $71 \mathrm{ng} \mathrm{g}^{-1}$ to $241 \mathrm{ng} \mathrm{g}^{-1}$ and that plastics usually contain $0.5-5 \%$ of PAEs, our results suggest that, after three months, more than $90 \%$ of the PAEs in the plastic remain and will ultimately leach out over a longer period of time.

\section{ASSOCIATED CONTENT}

\section{S Supporting Information}

FTIR-ATR analyses of PE-bag and PVC-cable fragments; kinetic of DOC leached; physiochemical properties, bacterial abundance and $\sum$ PAEs concentration o the sample (PDF)

\section{AUTHOR INFORMATION}

\section{Corresponding Author}

*E-mail: richard.sempere@mio.osupytheas.fr.

ORCID $\odot$

Andrea Paluselli: 0000-0002-4468-9802

Notes

The authors declare no competing financial interest.

\section{ACKNOWLEDGMENTS}

This study was conducted as part of the PLASTOX-JPI Ocean and PlasticMicro-EC2CO/CNRS projects. We acknowledge the financial support from the PACA region, which provided a $\mathrm{PhD}$ scholarship for A. Paluselli. The M I O flow cytometry and the SAM platforms are acknowledged for bacterial counting and seawater sampling, respectively. The authors are grateful to François-Xavier Perrin, Nathalie Patel, and Ahmad Fahs from Toulon University for kindly providing FTIR and SEM analyses. Dr. M. Ourgaud is kindly acknowledged for help during the experimental part of the study. The project leading to this publication has received funding from the European FEDER Fund under Project 116639417. Reviewers and editor are kindly acknowledged for improving the revised version of the MS.

\section{REFERENCES}

(1) Andrady, A. L. Microplastics in the marine environment. Mar. Pollut. Bull. 2011, 62, 1596-1605.

(2) Plastics Europe. Plastics-The facts 2017: An Analysis of European Plastics Production, Demand and Waste Data; Plastics Europe: Bruxelles, 2017.

(3) Eriksen, M.; Lebreton, L. C. M.; Carson, H. S.; Thiel, M.; Moore, C. J.; Borerro, J. C.; Galgani, F.; Ryan, P. G.; Reisser, J. Plastic pollution in the World's Ocean; More than 5 Trillion Plastic Peaces Weighing over 250.000 Tons Afloat at Sea. PLoS One 2014, 9 (12), e111913.

(4) Saido, K.; Koizumi, K.; Sato, H.; Ogawa, N.; Kwon, B. G.; Chung, S. Y.; Kusui, T.; Nishimura, M.; Kodera, Y. New analytical method for the determination of styrene oligomers formed from polystyrene decomposition and its application at the coastlines of the North-West Pacific Ocean. Sci. Total Environ. 2014, 473-474, 490495.
(5) Barnes, D. K. A.; Galgani, F.; Thompson, R. C.; Barlaz, M. Accumulation and fragmentation of plastic debris in global environments. Philos. Trans. R. Soc., B 2009, 364 (1526), 1985-1998.

(6) Ter Halle, A.; Ladirat, L.; Gendre, X.; Goudouneche, D.; Pusineri, C.; Routaboul, C.; Tenailleau, C.; Duployer, B.; Perez, E. Understanding the fragmentation pattern of marine plastic debris. Environ. Sci. Technol. 2016, 50, 5668-5675.

(7) Moore, C. J.; Moore, S. L.; Leecaster, M. K.; Weisberg, S. B. A comparison of plastic and plankton in the North Pacific Central Gyre. Mar. Pollut. Bull. 2001, 42 (12), 1297-1300.

(8) Woodall, L. C.; Sanchez-Vidal, A.; Canals, M.; Paterson, G. L. J.; Coppock, R.; Sleight, V.; Calafat, A.; Rogers, A. D.; Narayanaswamy, B. E.; Thompson, R. C. The deep sea is a major sink for microplastic debris. R. Soc. Open Sci. 2014, 1, 140317.

(9) Cooper, D. A.; Corcoran, P. L. Effects of mechanical and chemical processes on the degradation of plastic beach debris on the island of Kauai, Hawaii. Mar. Pollut. Bull. 2010, 60 (5), 650-654.

(10) Neves, D.; Sobral, P.; Ferreira, J. L.; Pereira, T. Ingestion of microplastics by commercial fish off the Portuguese coast. Mar. Pollut. Bull. 2015, 101, 119-126.

(11) Browne, M. A.; Crump, P.; Niven, S. J.; Teuten, E. L.; Tonkin, A.; Galloway, T.; Thompson, R. C. Accumulations of microplastic on shorelines worldwide: sources and sinks. Environ. Sci. Technol. 2011, 45, 9175-9179.

(12) Suaria, G.; Avio, C. G.; Mineo, A.; Lattin, G. L.; Magaldi, M. G.; Belmonte, G.; Moore, C. J.; Regoli, F.; Aliani, S. The Mediterranean Plastic Soup: synthetic polymers in Mediterranean surface waters. Sci. Rep. 2016, 6, 37551.

(13) Andrady, A. L.; Neal, M. A. Applications and societal benefits of plastics. Philos. Trans. R. Soc., B 2009, 364, 1977-1984.

(14) Cozar, A.; Echavarria, F.; Gonzalez-Gordillo, J. I.; Irigoien, X.; Ubeda, B.; Hernandez-Leon, S.; Palma, A. T.; Navarro, S.; Garcia-deLomas, J.; Tuiz, A.; Fernandez-de-Puelles, M. L.; Duarte, C. M. Plastic debris in the open ocean. Proc. Natl. Acad. Sci. U. S. A. 2014, 111 (28), 10239-10244.

(15) Romera-Castillo, C.; Pinto, M.; Langer, T. M.; Alvarez-Salgado, X. A.; Herndl, G. J. Dissolved organic carbon leaching from plastics stimulates microbial activity in the ocean. Nat. Commun. 2018, 9, 1430.

(16) Corcoran, P. L.; Biesinger, M. C.; Grifi, M. Plastics and beaches: a degrading relationship. Mar. Pollut. Bull. 2009, 58, 80-84.

(17) Devriese, L. I.; van der Meulen, M. D.; Maes, T.; Bekaert, K.; Paul-Pont, I.; Frere, L.; Robbens, J.; Vethaak, A. D. Microplastic contamination in brown shrimp(Crangon crangon, Linnaeus 1758) from coastal waters of the Southern North Sea and Channel area. Mar. Pollut. Bull. 2015, 98, 179-187.

(18) Rochman, C. M.; Tahir, A.; Williams, S. L.; Baxa, D. V.; Lam, R.; Miller, J. T.; Teh, F.-C.; Werorilangi, S.; Teh, S. J. Anthropogenic debris in seafood: plastic debris and fibers from textiles in fish and bivalves sold for human consumption. Sci. Rep. 2015, 5, No. 14340, DOI: $10.1038 /$ srep 14340 .

(19) Sussarellu, R.; Suquet, M.; Thomas, Y.; Lambert, C.; Fabioux, C.; Pernet, M. E. J.; LeGoïc, N.; Quillien, V.; Mingant, C.; Epelboin, Y.; Corporeau, C.; Guyomarch, J.; Robbens, J.; Paul-Pont, I.; Soudant, P.; Huvet, A. Oyster reproduction is affected by exposure to polystyrene microplastics. Proc. Natl. Acad. Sci. U. S. A. 2016, 113, $2430-2435$.

(20) Van Cauwenberghe, L.; Claessens, M.; Vandegehuchte, M. B.; Janssen, C. R. Microplastics are taken up by mussels (Mytilus edulis) and lugworms (Arenicolamarina) living in natural habitats. Environ. Pollut. 2015, 199, 10-17.

(21) Lusher, A. L.; Hernandez-Milian, G.; O’Brien, J.; Berrow, S.; O'Connor, I.; Officer, R. Microplastic and macroplastic ingestion by a deep diving, oceanic cetacean: the True's beaked whale Mesoplodon mirus. Environ. Pollut. 2015, 199, 185-191.

(22) Eriksson, C.; Burton, H. Origins and biological accumulation of small plastic particles in fur seals from Macquarie island. Ambio 2003, $32,380-384$. 
(23) Serôdio, P.; Nogueira, J. M. F. Considerations on ultra-trace analysis of phthalates in drinking water. Water Res. 2006, 40 (13), 2572-2582.

(24) Net, S.; Sempéré, R.; Delmont, A.; Paluselli, A.; Ouddane, B. Occurrence, Fate, Behavior and Ecotoxicological State of Phthalates in Different Environmental Matrices. Environ. Sci. Technol. 2015, 49 (7), 4019-4035.

(25) Commission staff Working Document on the Implementation of the Community Strategy for Endocrine Disrupters-A Range of Substances Suspected of Interfering with the Hormone System of Humans and Wildlife; CEC (Commission of the European Communities): Brussels, 2007.

(26) Crisp, T. M.; Clegg, E. D.; Cooper, R. L.; Wood, W. P.; Anderson, D. G.; Baetcke, K. P.; Hoffmann, J. L.; Morrow, M. S.; Rodier, D. J.; Schaeffer, J. E.; Touart, L. W.; Zeeman, M. G.; Patel, Y. M. Environmental endocrine disruption: an effects assessment and analysis. Environ. Health Perspect. 1998, 106 (1), 11-56.

(27) Latini, G. Monitoring phthalate exposure in humans. Clin. Chim. Acta 2005, 361 (1-2), 20-29.

(28) Kamrin, M. A. Phthalate Risks, Phthalate Regulation, and Public Health: A Review. J. Toxicol. Environ. Health, Part B 2009, 12 (2), 157-174.

(29) Meeker, J. D.; Sathyanarayana, S.; Swan, S. H. Phthalates and other additives in plastics: human exposure and associated health outcomes. Philos. Trans. R. Soc., B 2009, 364 (1526), 2097-2113.

(30) Matsumoto, M.; Hirata-Koisumi, M.; Ema, M. Potential adverse effects of phthalic acid esters on human health: a review of recent studies on reproduction. Regul. Toxicol. Pharmacol. 2008, 50, $37-49$.

(31) Fossi, M. C.; Romeo, T.; Baini, M.; Panti, C.; Marsili, L.; Campani, T.; Canese, S.; Galgani, F.; Druon, J. N.; Airoldi, S.; Taddei, S.; Fattorini, M.; Brandini, C.; Lapucci, C. Plastic debris occurrence, convergence areas and fin whales feeding ground in the Mediterranean marine protected area Pelagos Sanctuary: A modeling approach. Front. Mar. Sci. 2017, 4, 1-15.

(32) Net, S.; Dumoulin, D.; El-Osmani, R.; Rabodonirina, S.; Ouddane, B. Case study of PAHs, Me-PAHs, PCBs, Phthalates, and Pesticides Contamination in the Somme River water, France. Int. J. Environ. Res. 2014, 8 (4), 1159-1170.

(33) Paluselli, A.; Aminot, Y.; Galgani, F.; Net, S.; Sempéré, R. Occurrence of phthalate acid esters (PAEs) in the northwestern Mediterranean Sea and the Rhone River. Mermex special issue. Prog. Oceanogr. 2018, 163, 221-231.

(34) Paluselli, A.; Fauvelle, V.; Schmidt, N.; Galgani, F.; Net, S.; Sempéré, R. Seasonal distribution of phthalates in Mediterranean coastal seawater. Sci. Total Environ. 2018, 621 (2018), 578-587.

(35) Wang, I.; Lin, C.; Lin, Y.; Hsieh, W.; Chen, P. Early life phthalate exposure and atopic disorders in children: A prospective birth cohort study. Environ. Int. 2014, 62, 48-54.

(36) Xie, Z.; Ebinghaus, R.; Temme, C.; Lohmann, R.; Caba, A.; Ruck, W. Occurrence and Air-Sea Exchange of Phthalates in the Arctic. Environ. Sci. Technol. 2007, 41, 4555-4560.

(37) Gao, J.; Chi, J. Biodegradation of phthalate acid esters by different marine microalgal species. Mar. Pollut. Bull. 2015, 99, 7075 .

(38) Munshi, A. B.; Karim, N.; Shaukat, S.; Hashmi, D.; Boardman, G. D.; Flick, G. J. Toxicity of Phthalate Esters in Fish and Shellfish from Virginia Beach Using Matrix Solid Phase Dispersion (MSPD) and GC-MS. J. Chem. Soc. Pak. 2013, 35 (6), 1463-1471.

(39) Sempéré, R.; Para, J.; Tedetti, M.; Chattière, B.; Mallet, M. Variability of Solar radiation and CDOM in Surface Coastal Waters of the Northwestern Mediterranean Sea. Photochem. Photobiol. 2015, 91 (4), 851-561.

(40) Castro-Jiménez, J.; Barhoumi, B.; Paluselli, A.; Tedetti, M.; Jiménez, B.; Muñoz-Arnanz, J.; Wortham, H.; Driss, M. D.; Sempéré, R. Occurrence, Loading, and Exposure of Atmospheric Particle-Bound POPs at the African and European Edges of the Western Mediterranean Sea. Environ. Sci. Technol. 2017, 51, 13180.
(41) Theodosi, C.; Panagiotopoulos, C.; Nouara, A.; Zarmpas, P.; Violaki, K.; Kanakidou, M.; Sempéré, R.; Mihalopoulos, N. Sugars in atmospheric aerosols over the Eastern Mediterranean. Prog. Oceanogr. 2018, 163, 70-81.

(42) The Mermex Group. Marine ecosystems responses to climatic and anthropogenic forcings in the Mediterranean. Progr. Oceanogr. 2011, 91, 97-166.

(43) Zorita, I.; Apraiz, I.; Ortiz-Zarragoitia, M.; Orbea, A.; Cancio, I.; Soto, M.; Marigomez, I.; Cajaraville, M. P. Assessment of biological effects of environmental pollution along the NW Mediterranean Sea using mussels as sentinel organisms. Environ. Pollut. 2007, 148 (1), $236-250$.

(44) Cozar, A.; Sanz-Martin, M.; Marti, E.; Gonzalez-Gordillo, J. I.; Ubeda, B.; Galvez, J. A.; Irigoien, X.; Duarte, C. M. Plastic accumulation in the Mediterranean Sea. PLoS One 2015, 10 (4), e0121762.

(45) Collignon, A.; Hecq, J. H.; Galgani, F.; Collard, F.; Goffart, A. Annual variation in neustonic micro- and meso-plastic particles and zooplankton in the Bay of Calvi (Mediterranean-Corsica). Mar. Pollut. Bull. 2014, 79, 293-298.

(46) Fossi, M. C.; Marsili, L.; Baini, M.; Giannetti, M.; Coppola, D.; Guerranti, C.; Caliani, I.; Minutoli, R.; Lauriano, G.; Finoia, M. G.; Rubegni, F.; Panigada, S.; Berube, M.; Ramirez, J. U.; Panti, C. Fin whales and microplastics: The Mediterranean Sea and the Sea of Cortez scenarios. Environ. Pollut. 2016, 209, 68-78.

(47) Wang, C. Y.; Wang, F.; Wang, T.; Yang, X. L.; Bian, Y. R.; Kengara, F. O.; Li, Z. B.; Jiang, X. Effects of Autoclaving and Mercuric Chloride Sterilization on PAHs Dissipation in a Two-Liquid-Phase Soil Slurry. Pedosphere 2011, 21, 56-64.

(48) Yu, J. T.; Bouwer, E. J.; Coelhan, M. Occurrence and biodegradability studies of selected pharmaceuticals and personal care products in sewage effluent. Agric. Water Manag. 2006, 86, 72-80.

(49) Aminot, Y.; Fuster, L.; Pardon, P.; Le Menach, K.; Budzinski, $\mathrm{H}$. Suspended solids moderate the degradation and sorption of waste water-derived pharmaceuticals in estuarine waters. Sci. Total Environ. 2018, 15, 39-40.

(50) Girault, M.; Arakawa, H.; Ceccaldi, H. J.; Hashihama, F.; Gregori, G. Heterotrophic prokaryote distribution along a $2300 \mathrm{~km}$ transect in the North Pacific subtropical gyre during a strong La Nina conditions: relationship between distribution and hydrological conditions. Biogeosciences 2015, 12, 3607-3621.

(51) Sempéré, R.; Tedetti, M.; Panagiotopoulos, C.; Charrière, B.; Van Wambeke, F. Distribution and bacterial availability of dissolved neutral sugars in the South East Pacific. Biogeosciences 2008, 5, 11651173.

(52) Sempéré, R.; Yoro, S. C.; Van Wambeke, F.; Charrière, B. Microbial decomposition of large organic particles in northwestern Mediterranean Sea. Mar. Ecol.: Prog. Ser. 2000, 5 (198), 61-72.

(53) Ter Halle, A.; Ladirat, L.; Martignac, M.; Mingotaud, A. F.; Boyron, O.; Perez, E. To what extent are microplastic from the open ocean weathered? Environ. Pollut. 2017, 227, 167-174.

(54) Liang, D.; Zhang, T.; Fang, H.; He, J. Phthalates biodegradation in the environment. Appl. Microbiol. Biotechnol. 2008, 80, 183-198.

(55) Kumar, V.; Sharma, N.; Maitra, S. S. Comparative study on the degradation of dibutyl phthalate by two newly isolated Pseudomonas sp. V21b and Comamonas sp. 51F. Biotechnol Rep. (Amst). 2017, 15, $1-10$.

(56) Amir, S.; Hafidi, M.; Merlina, G.; Hamdi, H.; Jouraiphy, A.; El Gharous, M.; Revel, J. C. Fate of phthalic acid esters during composting of both lagooning and activated sludges. Process Biochem. 2005, 40, 2183-2190.

(57) Cartwright, C. D.; Owen, S. A.; Thompson, I. P.; Burns, R. G. Biodegradation of diethyl phthalate in soil by a novel pathway. FEMS Microbiol. Lett. 2000, 186, 27-34.

(58) Kleerebezem, R.; Pol, L. W. H.; Lettinga, G. Anaerobic biodegradation of phthalic acid and isomers and related compounds. Biodegradation 1999, 10, 63-73. 
(59) Yuan, S. Y.; Liu, C.; Liao, C. S.; Chang, B. V. Occurrence and microbial degradation of phthalate esters in Taiwan river sediments. Chemosphere 2002, 49, 1295-1299.

(60) Xu, X. R.; Li, H. B.; Gu, J. B.; Li, X. Y. Kinetics of n-butyl benzyl phthalate degradation by a pure bacterial culture from the mangrove sediment. J. Hazard. Mater. 2007, 140, 194-199.

(61) Jin, D.; Kong, X.; Cui, B.; Bai, Z.; Zhang, H. Biodegradation of Di-n-Butyl Phthalate by a Newly Isolated Halotolerant Sphingobium sp. Int. J. Mol. Sci. 2013, 14, 24046-24054.

(62) Xu, X.-R.; Gu, J.-D.; Li, H.-B.; Li, X.-Y. Kinetics of di-n-Butyl Phthalate Degradation by a Bacterium Isolated from Mangrove Sediment. J. Microbiol. Biotechnol. 2005, 15 (5), 946-951.

(63) Kim, Y. H.; Lee, J. W.; Ahn, J. Y.; Gu, M. B.; Moon, S. H. Enhanced degradation of an endocrine-disrupting chemical, butyl benzyl phthalate, by Fusarium oxysporum f. sp pisi cutinase. Appl. Environ. Microbiol. 2002, 68, 4684-4688.

(64) Iwaki, H.; Nishimura, A.; Hasegawa, Y. Tropicibacter phthalicus sp. nov.; A Phthalate-Degrading Bacterium from Seawater. Curr. Microbiol. 2012, 64, 392-396.

(65) Vamsee-Krishna, C.; Mohan, Y.; Phale, P. S. Biodegradation of phthalate isomers by Pseudomonas aeruginosa PP4, Pseudomonas sp PPD and Acinetobacter lwoffii ISP4. Appl. Microbiol. Biotechnol. 2006, 72, 1263-1269.

(66) Xu, X. R.; Li, H. B.; Gu, J. D. Elucidation of n-butyl benzyl phthalate biodegradation using high-performance liquid chromatography and gas chromatography-mass spectrometry. Anal. Bioanal. Chem. 2006, 386, 370-375.

(67) Wang, Y. Y.; Fan, Y. Z.; Gu, J. D. Aerobic degradation of phthalic acid by Comamonas acidovoran Fy-1 and dimethyl phthalate ester by two reconstituted consortia from sewage sludge at high concentrations. World J. Microbiol. Biotechnol. 2003, 19, 811-815.

(68) Gu, J. D.; Li, J.; Wang, Y. Biochemical pathway and degradation of phthalate ester isomers by bacteria. Water Sci. Technol. 2005, 52, 241-248.

(69) Yuwatini, E.; Hata, N.; Taguchi, S. Behavior of di-(2ethylhexyl) phthalate discharged from domestic waste water into aquatic environment. J. Environ. Monit. 2006, 8, 191-196.

(70) Li, B.; Chi, J.; Wu, W. X.; Wang, Z. K. Effects of nutrients and light on biodegradation of dibuyl phthalate and di-2-ethylexyl phthalate in haihe estuary. Bull. Environ. Contam. Toxicol. 2007, 79, 80-83.

(71) Hermabessiere, L.; Dehaut, A.; Paul-Pont, I.; Lacroix, C.; Jezequel, R.; Soudant, P.; Duflos, G. Occurrence and effects of plastic additives on marine environments and organisms: A review. Chemosphere 2017, 182, 781-793.

(72) Hahladakis, J. N.; Velis, C. A.; Weber, R.; Iacovidou, E.; Purnell, P. An overview of chemical additives present in plastics: Migration, release, fate and environmental impact during their use, disposal and recycling. J. Hazard. Mater. 2017, 344, 179.

(73) Wagner, M.; Oehlmann, J. Endocrine disruptors in bottled mineral water: total estrogenic burden and migration from plastic bottles. Environ. Sci. Pollut. Res. 2009, 16, 278-286.

(74) Montuori, P.; Jover, E.; Morgantini, M.; Bayona, J. M.; Triassi, M. Assessing human exposure to phthalic acid and phthalate esters from mineral water stored in polyethylene terephthalate and glass bottles. Food Addit. Contam., Part A 2008, 25, 511-518.

(75) Fasano, E.; Bono-Blay, F.; Cirillo, T.; Montuori, P.; Lacorte, S. Migration of phthalates, alkylphenols, bisphenol $\mathrm{A}$ and $\mathrm{di}(2$ ethylhexyl)adipate from food packaging. Food Control 2012, 27 (1), $132-138$.

(76) Casajuana, N.; Lacorte, S. Presence and release of phthalic esters and other endocrine disrupting compounds in drinking water. Chromatographia 2003, 57, 649-655.

(77) Simoneau, C.; Van den Eede, L.; Valzacchi, S. Identification and quantification of the migration of chemicals from plastic baby bottles used as substitutes for polycarbonate. Food Addit. Contam., Part A 2012, 29, 469-480.

(78) Xu, Q.; Yin, X.; Wang, M.; Wang, H.; Zhang, H.; Shen, Y.; Xu, S.; Zhang, L.; Gu, Z. Analysis of Phthalate Migration from Plastic
Containers to Packaged Cooking Oil and Mineral Water. J. Agric. Food Chem. 2010, 58, 11311-11317.

(79) Bosnir, J.; Puntaric, D.; Galic, A.; Skes, I.; Dijanic, T.; Klaric, M.; Grgic, M.; Curkovic, M.; Smit, Z. Migration of Phthalates from Plastic Containers into Soft Drinks and Mineral Water. Food Technol. Biotechnol. 2007, 45 (1), 91-95.

(80) Li, C.; Chen, J.; Wang, J.; Han, P.; Luan, Y.; Ma, X.; Lu, A. Phthalate esters in soil, plastic film, and vegetable from greenhouse vegetable production bases in Beijing, China: Concentration, sources, and risk assessment. Sci. Total Environ. 2016, 568, 1037-1043.

(81) Suhrhoff, T. J.; Scholz-Bottcher, B. M. Qualitative impact of salinity, UV radiation and turbulence on leaching of organic plastic additives from four common plastics- A lab experiment. Mar. Pollut. Bull. 2016, 102, 84-94.

(82) Teuten, E. L.; Saquing, J. M.; Knappe, D. R. U.; Barlaz, M. A.; Jonsson, S.; Bjorn, A.; Rowland, S. J.; Thompson, R. C.; Galloway, T. S.; Yamashita, R.; Ochi, D.; Watanuki, Y.; Moore, C.; Viet, P. H.; Tana, T. S.; Prudente, M.; Boonyatumanond, R.; Zakaria, M. P.; Akkhavong, K.; Ogata, Y.; Hirai, H.; Iwasa, S.; Mizukawa, K.; Hagino, Y.; Imamura, A.; Saha, M.; Takada, H. Transport and release of chemicals from plastics to the environment and to wildlife. Philos. Trans. R. Soc., B 2009, 364, 2027-2045.

(83) Schmidt, N.; Thibault, D.; Galgani, F.; Paluselli, A.; Sempéré, $\mathrm{R}$. Occurrence of microplastics and potential contribution of phthalates in the surface waters of the Gulf of Lion (NW Mediterranean Sea). Prog. Oceanogr. 2018, 163, 214-220.

(84) Sanchez-Avila, L.; Tauler, R.; Lacorte, S. Organic micropollutants in coastal waters from NW Mediterranean Sea: Sources distribution and potential risk. Environ. Int. 2012, 46, 50-62.

(85) Jambeck, L. R.; Geyer, R.; Wilcox, C.; Siegler, T. R.; Perryman, M.; Andrady, A.; Narayan, R.; Law, K. L. Plastic waste inputs from land into the ocean. Science 2015, 347, 768-771.

(86) Riou, V.; Para, J.; Garel, M.; Guigue, C.; Ali, B. A.; Santinelli, C.; Lefevre, D.; Gattuso, J. P.; Goutx, M.; Jacquet, S. H. M.; Le Moigne, F.; Tachikawa, K.; Tamburini, C. Biodegradation of Emiliania huxleyi Aggregates by a Natural Mediterranean Prokaryotic Community under Increasing Hydrostatic Pressure. Prog. Oceanogr. 2018, 163, 271-281. 